\title{
Synthesis of interesting $\beta$-nitrohydrazides through thiourea organocatalysed aza-Michael addition
}

\author{
Ana Alcaine, ${ }^{a}$ Eugenia Marqués-López ${ }^{* a}$ and Raquel P. Herrera* ${ }^{a}$ \\ The synthesis of antimicrobial $\beta$-nitrohydrazides, as the goal product of our reaction, is \\ reached by the first time under organocatalytic enantioselective conditions. We accomplish \\ this goal by using a thiourea organocatalysed aza-Michael addition reaction of hydrazide to \\ nitroalkenes, furnishing final products with good yields and good enantiomeric ratios. The \\ developed methodology is one of the scarce examples of catalytic reactivity using hydrazide \\ where the reaction proceeds through its $\mathrm{N}^{2}$ atom. Our developed strategy extends the \\ generality of this area of research due to the difficulties of designing new nitrogen \\ nucleophiles with high activity, and in addition, this is one of the scarce examples where \\ nitroalkenes and chiral thioureas have been used in asymmetric organocatalytic aza-Michael \\ addition reactions.
}

\section{Introduction}

$\beta$-Nitrohydrazides have been found to exhibit interesting biological properties and some patents have been focused on their synthesis. ${ }^{1}$ However, the only asymmetric synthesis of these compounds was reached by starting from the corresponding hydrazones and nitromethane and using a stoichiometric amount of a silicon Lewis acid promoter (Scheme 1, route a). ${ }^{1 \mathrm{~b}}$ In order to avoid the synthesis of the corresponding hydrazones and the use of a stoichiometric charge of the chiral promoter, we envisaged that a more straightforward organocatalytic aza-Michael addition reaction ${ }^{2,3}$ of hydrazide to nitroalkenes should be an interesting and rapid approach for achieving the same final goal (Scheme 1, route b).

As $\beta$-nitrohydrazides, many other important biomolecules also bear stereogenic centers containing $\mathrm{C}-\mathrm{N}$ bonds. ${ }^{4}$ For this purpose, the aza-Michael addition reaction is one of the most important protocols for $\mathrm{C}-\mathrm{N}$ bond formation and this field has undergone an impressive growth in the last decade, and special improvements have been achieved concerning the area of asymmetric organocatalysis., ${ }^{2,5}$ Valuable Michael acceptor substrates as well as attractive nitrogen-containing nucleophiles have been successfully explored affording biologically and synthetically important building blocks such as $\alpha_{-}{ }^{6}$ or $\beta$-amino acids ${ }^{7}$ or 1,2 -diamines, ${ }^{8}$ depending on the starting materials.

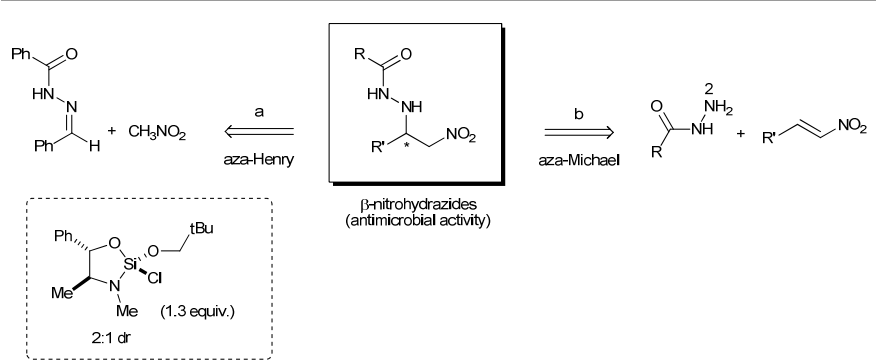

Scheme 1 Synthetic approaches to chiral $\beta$-nitrohydrazides

Moreover, hydrazide is a privileged structural motif present in many bioactive compounds with biological properties. ${ }^{9}$ Its use as starting material is however highly challenging, due to the necessary regiochemistry control on its ambident reactivity between the two competitive amine groups present in the structure. Its reactivity through the $\mathrm{N}^{1}$ has been explored in cross-coupling reactions or in Michael addition reactions (Scheme 2 , routes a and b, respectively), ${ }^{10}$ whereas its reactivity through the $\mathrm{N}^{2}$ has been almost limited to the synthesis of hydrazones (Scheme 2, route c). ${ }^{11}$ Consequently, the successful development of new methodologies of $\mathrm{N}^{2}$ Michael addition reactions still represents an active synthetic challenge, and only Feng and co-workers have recently reported a pioneering example using a chiral metal Lewis acid (Scheme 2, route d). ${ }^{12}$ 

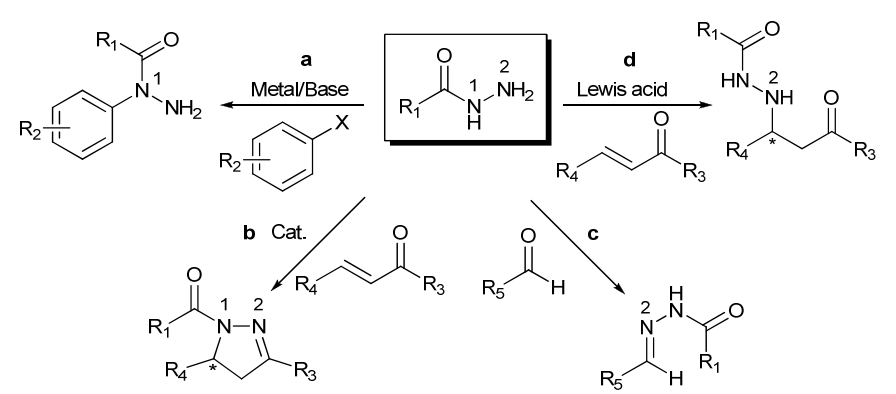

Scheme 2 Mode of reactivity exhibited by $N$-acylhydrazides

In connection with this, we disclose here our results concerning a pioneering strategy for the synthesis of chiral $\beta$ nitrohydrazides via thiourea-catalysed aza-Michael addition reaction of hydrazides to nitroalkenes (Scheme 3). To the best of our knowledge this is the first enantioselective organocatalysed example using hydrazide as suitable nucleophile in an aza-Michael addition reaction through its $\mathrm{N}^{2}$ group. Based on our own experience activating the versatile nitro group $^{13}$ in different organocatalytic reactions, ${ }^{14}$ we envisioned that catalysts acting through hydrogen bond interactions might be a useful tool to explore this ambiphilic reactivity. One of the main organocatalytic structures covering this large group is the thiourea/urea derivatives. ${ }^{14-16}$ In this context, a suitable activation of the nitro group through hydrogen bonds of a thiourea moiety with a reasonable concomitant coordination of the hydrazide group by an amine group present in the same catalyst, could drive the attack over the nitroalkene promoting this aza-Michael addition reaction in a bifunctional fashion (Figure 1). ${ }^{17,18}$

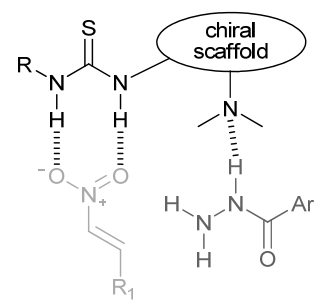

Fig. 1 Mechanistic hypothesis for a bifunctional mode of action

\section{Results and discussion}

In order to check the viability of the aforementioned hypothesis, we firstly evaluated the efficiency of catalyst $\mathbf{3 a}^{19}$ in the addition of hydrazides $\mathbf{1 a - c}$ to nitrostyrene $\mathbf{2 a}$ as model reaction (Scheme 3).<smiles>[R]C(=O)NN</smiles>

1a R: $\mathrm{Ph}$ 1b R: 4- $\mathrm{NO}_{2}-\mathrm{C}_{6} \mathrm{H}_{4}$ 1c R: 4-MeO- $\mathrm{C}_{6} \mathrm{H}_{4}$<smiles>[R]C(=O)NNC([R16])C[N+](=O)[O-]</smiles>

$\mathrm{CH}_{3} \mathrm{CN}$, r.t., $18 \mathrm{~h}$

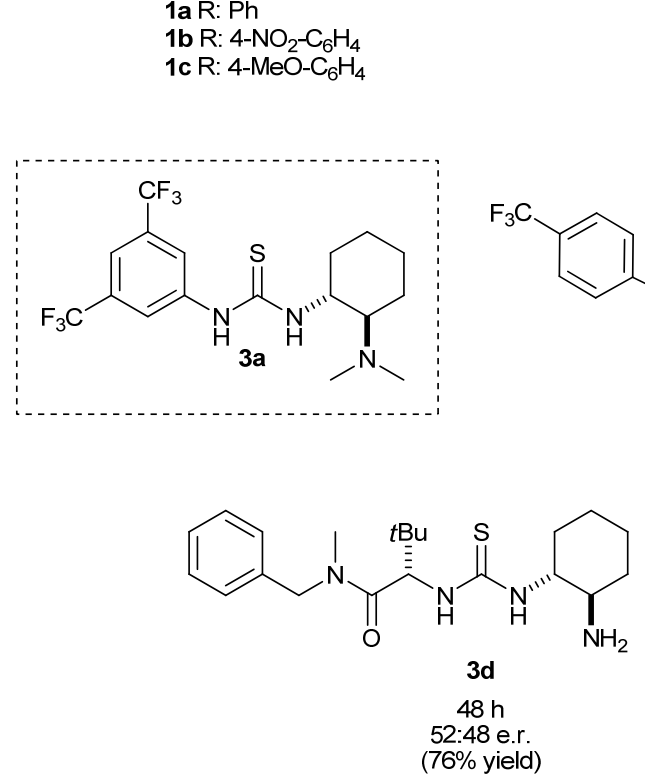

4aa $52: 48$ e.r. (63\% yield)

4ba $75: 25$ e.r. ( $>95 \%$ yield)

4ca $54: 46$ e.r. (83\% yield)

(76\% yield)<smiles>Nc1c(N[C@@H]2CCCCC2N2CCCCC2)c(=O)c1=O</smiles>
$60 \%$ yield)<smiles>C=CC1C2C=CC1N1CCC2C1C(NC(=S)Nc1cc(C(F)(F)F)cc(C(F)(F)F)c1)c1ccnc2ccc(OC)cc12</smiles>

Scheme 3 Test reaction to explore the thiourea catalysed aza-Michael addition

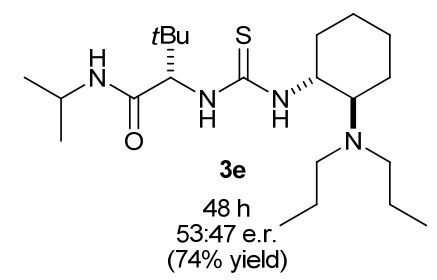

(74\% yield) 
To our delight, we obtained preliminary promising results in terms of reactivity and enantioselectivity using hydrazide $\mathbf{1 b}$ (75:25 e.r. and $>95 \%$ yield), even if the reaction has a considerable background at room temperature (see supporting information for values). In this context, it is noteworthy that we perform the reaction without excess of reactants in order to decrease the background reaction and additionally as an attractive feature from an atom economy point of view. ${ }^{20}$ Poorer results were reached with organocatalysts $\mathbf{3 b},{ }^{21} \mathbf{3} \mathbf{c},{ }^{22}$ $\mathbf{3 d},{ }^{23}$ and $\mathbf{3} \mathbf{e}^{24}$ tested under similar reaction conditions using hydrazide 1b (Scheme 3). Moreover, the final products were interestingly the result of the $\mathrm{N}^{2}$ attack by the hydrazide to the nitroalkene, complementing in this sense the reactivity observed so far in the literature with this kind of substrates for Michael addition reactions.

Encouraged by these results, and having identified Takemoto's catalyst 3a as the best one, we continued the screening varying different parameters in the reaction model in order to reach the optimal reaction conditions (Table 1) (see supporting information for a more complete screening).

Table 1 Screening of the reaction conditions. ${ }^{a}$

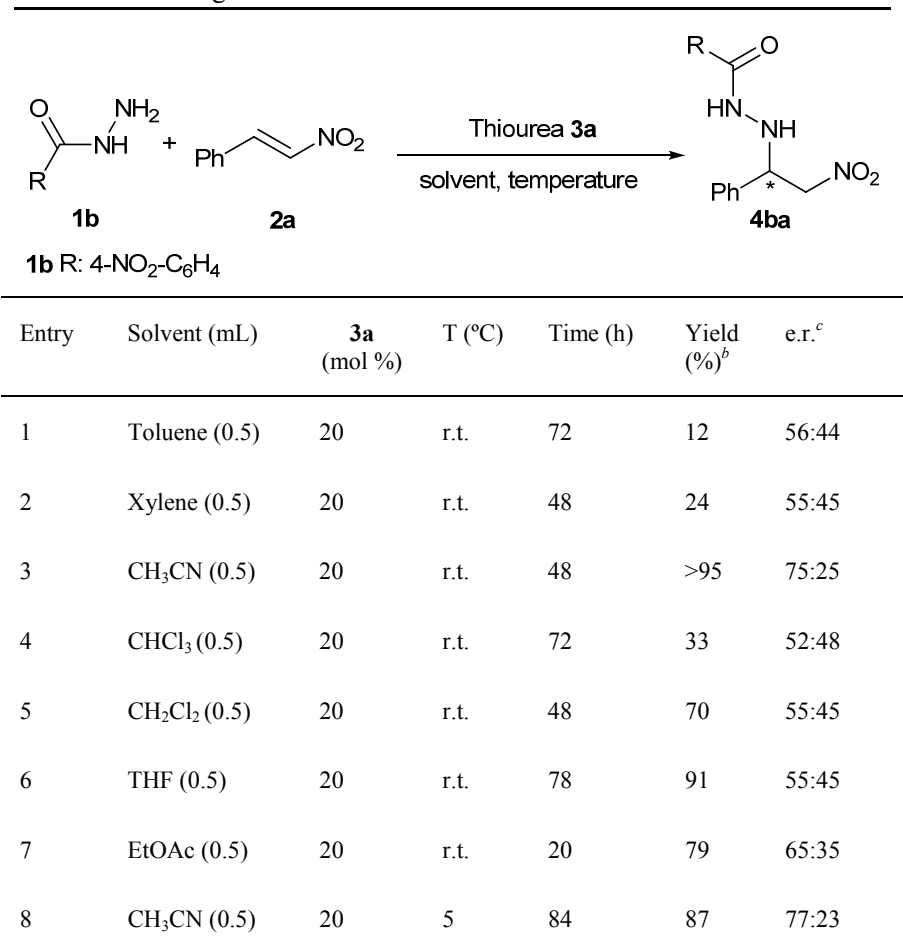

$\begin{array}{lllllll}9 & \mathrm{CH}_{3} \mathrm{CN}(0.5) & 10 & 5 & 40 & >95 & 67: 33 \\ 10 & \mathrm{CH}_{3} \mathrm{CN}(0.25) & 10 & 5 & 42 & >95 & 80: 20 \\ 11 & \mathrm{CH}_{3} \mathrm{CN}(0.5) & 20 & -27 & 93 & 91 & 82: 18 \\ 12 & \mathrm{CH}_{3} \mathrm{CN}(0.5) & 10 & -27 & 72 & 88 & 82: 18 \\ 13 & \mathrm{CH}_{3} \mathrm{CN}(0.25) & 10 & -27 & 84 & >95 & 88: 12 \\ 14 & \mathrm{CH}_{3} \mathrm{CN}(0.25) & 5 & -27 & 72 & 79 & 86: 14 \\ 15 & \mathrm{CH}_{3} \mathrm{CN}(0.25) & 20 & -35 & 48 & 12 & 70: 30 \\ 16 & \mathrm{CH}_{3} \mathrm{CN}(0.5) & 10 & -35 & 120 & 27 & 75: 25\end{array}$

${ }^{a}$ Experimental conditions: To a solution of thiourea 3a and nitrostyrene 2a $(0.1 \mathrm{mmol})$ in the corresponding solvent, hydrazide $\mathbf{1 b}(0.1 \mathrm{mmol})$ was added at the indicated temperature. After a reasonable reaction time, product $4 \mathbf{b a}$ was isolated by flash chromatography (Hex:EtOAc, 7:3). ${ }^{b}$ After isolation by column chromatography. ${ }^{c}$ Determined by chiral HPLC analysis (Chiralpak IC, 80:20 Hex:EtOAc, $1 \mathrm{~mL} / \mathrm{min})$.

In an initial screening of solvents at room temperature (entries 1-7), $\mathrm{CH}_{3} \mathrm{CN}$ (entry 3) and EtOAc (entry 7) were identified as the solvents of choice for further variations, since they led to the highest values of enantiomeric ratio. Although we also continued with EtOAc in the ensuing screenings (see supporting information), we finally decided to proceed with $\mathrm{CH}_{3} \mathrm{CN}$ because slightly better results were rendered for similar conditions. It was found that lowering the temperature to 5 or $27{ }^{\circ} \mathrm{C}$ improved enantiomeric ratios were achieved, although longer reaction times were required (entries 8 and 11). Decreasing the catalyst loading until 10 or $5 \mathrm{~mol} \%$, and increasing the concentration of the reaction mixture had a positive effect on the enantioselectivity without altering the final yield (entries 13 and 14). Unfortunately, experiments made lowering further the temperature to $-35{ }^{\circ} \mathrm{C}$ afforded poorer enantioselectivities and yields (entries 15 and 16). Finally, the combination of $10 \mathrm{~mol} \%$ of catalyst 3a cooling down the reaction mixture to $-27{ }^{\circ} \mathrm{C}$ in $0.25 \mathrm{~mL}$ of $\mathrm{CH}_{3} \mathrm{CN}$, led to a slight increase in the asymmetric induction as well as in the yield, providing the best reaction conditions (entry 13).

Subsequently, and with the best reaction conditions in hand, we proceeded to evaluate the scope and limitations of this azaMichael reaction testing different nitroalkenes bearing electronwithdrawing and electron-donating groups, as well as aliphatic nitroolefins (Table 2). 


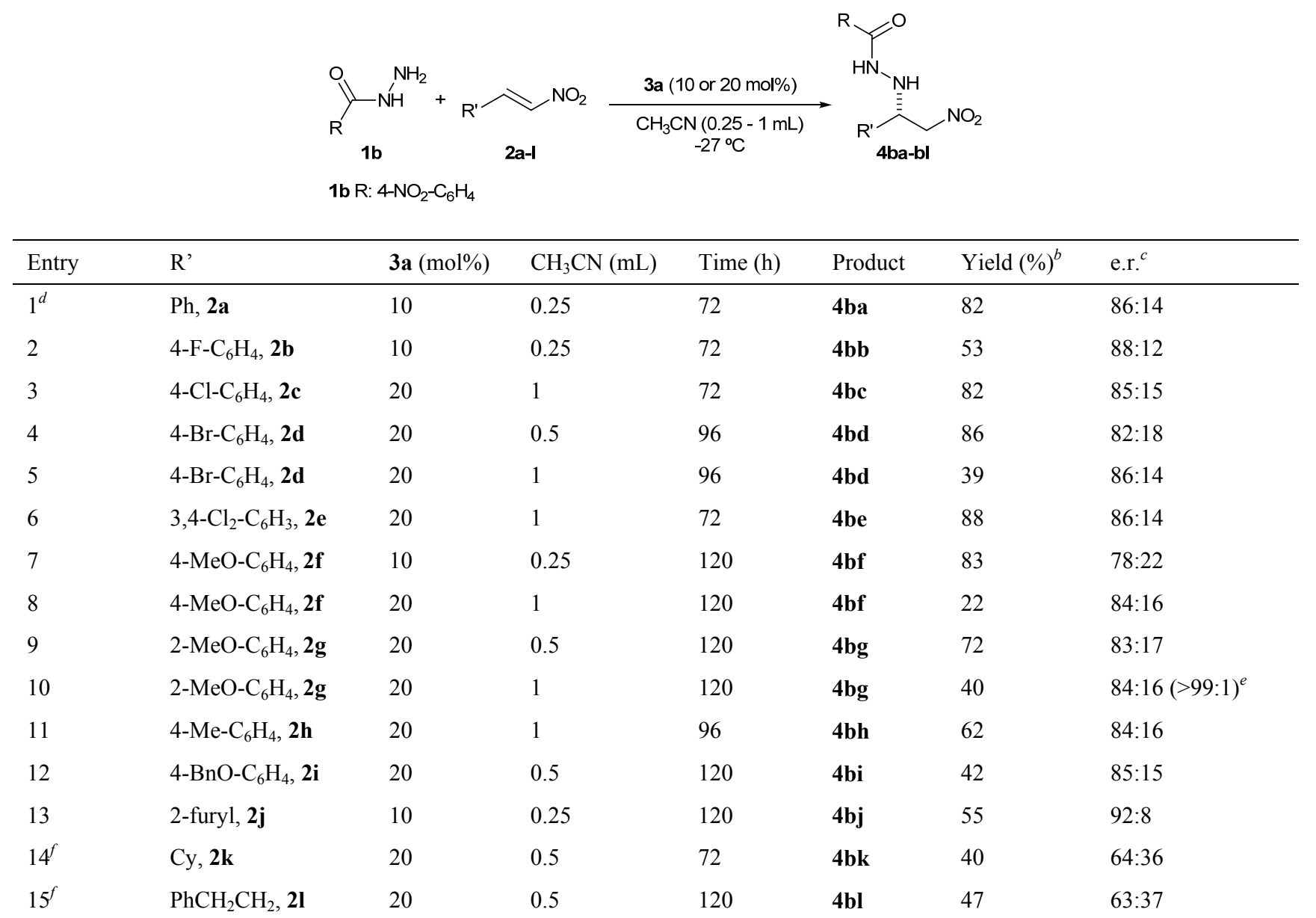

${ }^{a}$ Experimental conditions: To a solution of thiourea 3a and nitroalkenes $\mathbf{2 a - 1}(0.1 \mathrm{mmol})$ in $\mathrm{CH}_{3} \mathrm{CN}$, hydrazide $\mathbf{1 b}(0.1$ mmol $)$ was added at $-27{ }^{\circ} \mathrm{C}$. After the corresponding reaction time, products 4 ba-bl were isolated by flash chromatography (Hex:EtOAc, $7: 3$ ). ${ }^{b}$ After isolation by column chromatography. ${ }^{c}$ Determined by chiral HPLC analysis (Chiralpak IC, 80:20 Hex:EtOAc, $1 \mathrm{~mL} / \mathrm{min}$ ). ${ }^{d}$ Reaction performed with 0.5 mmol of nitroalkene 2a. ${ }^{e}$ Value obtained after recrystallization. ${ }^{f}$ Reaction performed at $-35{ }^{\circ} \mathrm{C}$.

As shown in Table 2, hydrazide 1b was successfully added to different electron-rich and electron-poor nitroalkenes rendering final adducts $\mathbf{4}$ with moderate to high yields and good enantiomeric ratios. In some cases, slightly modified reaction conditions were required to improve the results. For example, we observed higher enantioselectivities in some cases under more diluted conditions although with poorer yields (compare entries 4 and 5, 7 and 8, 9 and 10). The data do not suggest a clear correlation between the electronic properties of nitroalkenes and the enantioselectivity, although longer reaction times were required with electron-donor groups in the aromatic ring of the nitroolefins. Notably, using a heteroaromatic nitroalkene afforded the highest value of enantiomeric ratio (entry 13). In contrast, poorer results were furnished with aliphatic nitroolefins even to lower temperature and prolonged reaction times (entries 14 and 15). As a consequence, we cannot rule out a possible $\pi$-stacking interaction between the hydrazide and the aromatic ring of nitroalkenes, ${ }^{25}$ which might play an important role determining the preferred orientation in the attack. The lack of such interaction could justify the poor enantioselectivities observed using aliphatic substituents. We also scaled up the reaction to $0.5 \mathrm{mmol}$ (entry 1) and it is worthwhile to note that similar results were provided to those previously furnished with $0.1 \mathrm{mmol}$ (Table 1 , entry 13 ).

The straightforward procedure for obtaining the final goal described here is simpler and "greener" than the pioneering protocol reported by Leighton and co-workers, ${ }^{1 \mathrm{~b}}$ because it is not necessary the use of stoichiometric amounts of the silicon Lewis acid promoter (1.3 equiv.). Additionally, a diastereomeric mixture $(1: 2)$ of the metal promoter is used in the patent and the absolute configuration for final products is not provided. Moreover, tedious conditions, anhydrous solvents or reagents and inert atmosphere are not required, as they are in the organometallic version. Furthermore, our most accessible catalyst 3a compared with that used in the reported patent 
makes our procedure a more attractive alternative for this chiral version.

In order to determine the absolute configuration of our products, single crystal was grown from adduct $4 \mathbf{b g}$, and the stereochemical outcome was determined to be $S$ for final product (Figure 2). ${ }^{26}$

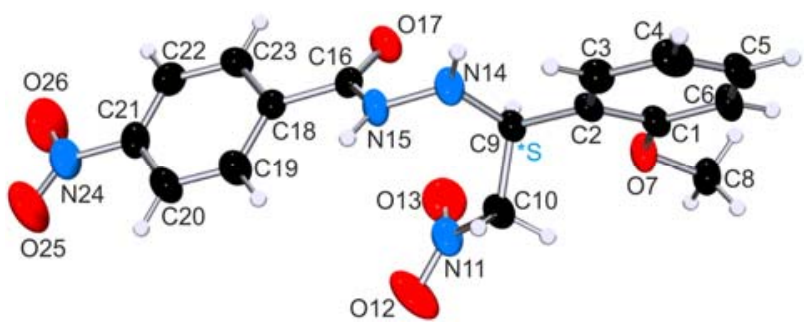

Fig. 2 X-ray crystal structure of (S)-4bg

We propose the following transition state to explain the role of the catalyst 3a based in previous mode of activation by this structure (Figure 3). The generally accepted mechanism in Michael addition reactions involves a suitable bidentate activation between the thiourea moiety and the nitro group, since the activation of nitroolefins by thiourea $\mathbf{3 a}$ has been earlier invoked in other processes. ${ }^{27}$ However, we cannot discard a reasonable simultaneous coordination of the hydrazide group by the amine group in a bifunctional fashion (Figure 3). ${ }^{18}$ The most acidic $\mathrm{N}^{1}$ (TS) could be involved in the assistance of the aza-Michael addition through a transient $\mathrm{N}-\mathrm{H}$ bond coordination, since the deprotonation of the hydrazide is unlikely due to the pKa values of both species. ${ }^{28}$ According to this stereochemical model, the amine would drive the approach of the nucleophile to the $S i$ face of the nitroalkene affording the $S$ absolute configuration in all final adducts, which is consistent with the observed results in our products.

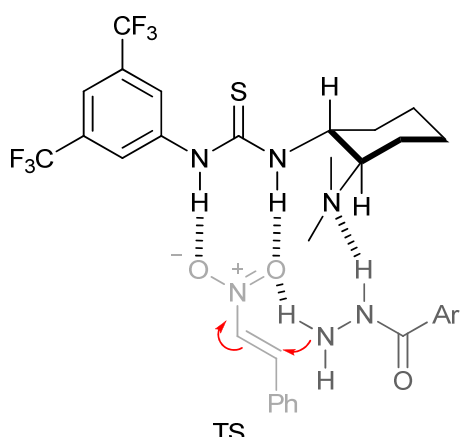

Fig. 3 Bifunctional mode of action

In order to support our proposed mechanism (Figure 1 and 3 ), we performed different ${ }^{1} \mathrm{H}-\mathrm{NMR}$ experiments (Figures 4-6). First, catalyst $\mathbf{3 a}(0.01 \mathrm{mmol})$, and hydrazide $\mathbf{1 b}(0.01 \mathrm{mmol})$ in $\mathrm{CD}_{3} \mathrm{CN}(0.5 \mathrm{~mL})$ were analysed separately in two NMR tubes at room temperature (Figure 4, spectra 1 and 2). Subsequently, a mixture of both, catalyst $\mathbf{3 a}$ and hydrazide $\mathbf{1 b}$ in the same concentration in $\mathrm{CD}_{3} \mathrm{CN}$, was analysed by ${ }^{1} \mathrm{H}-\mathrm{NMR}$ (Figure 4 , spectrum 3). Interestingly, the signals belonging to the $\mathrm{N}^{1} \mathrm{H}$ and $\mathrm{N}^{2} \mathrm{H}$ of the hydrazide disappeared in the latter spectrum, supporting a possible interaction between the NH's of the hydrazide and the catalyst.

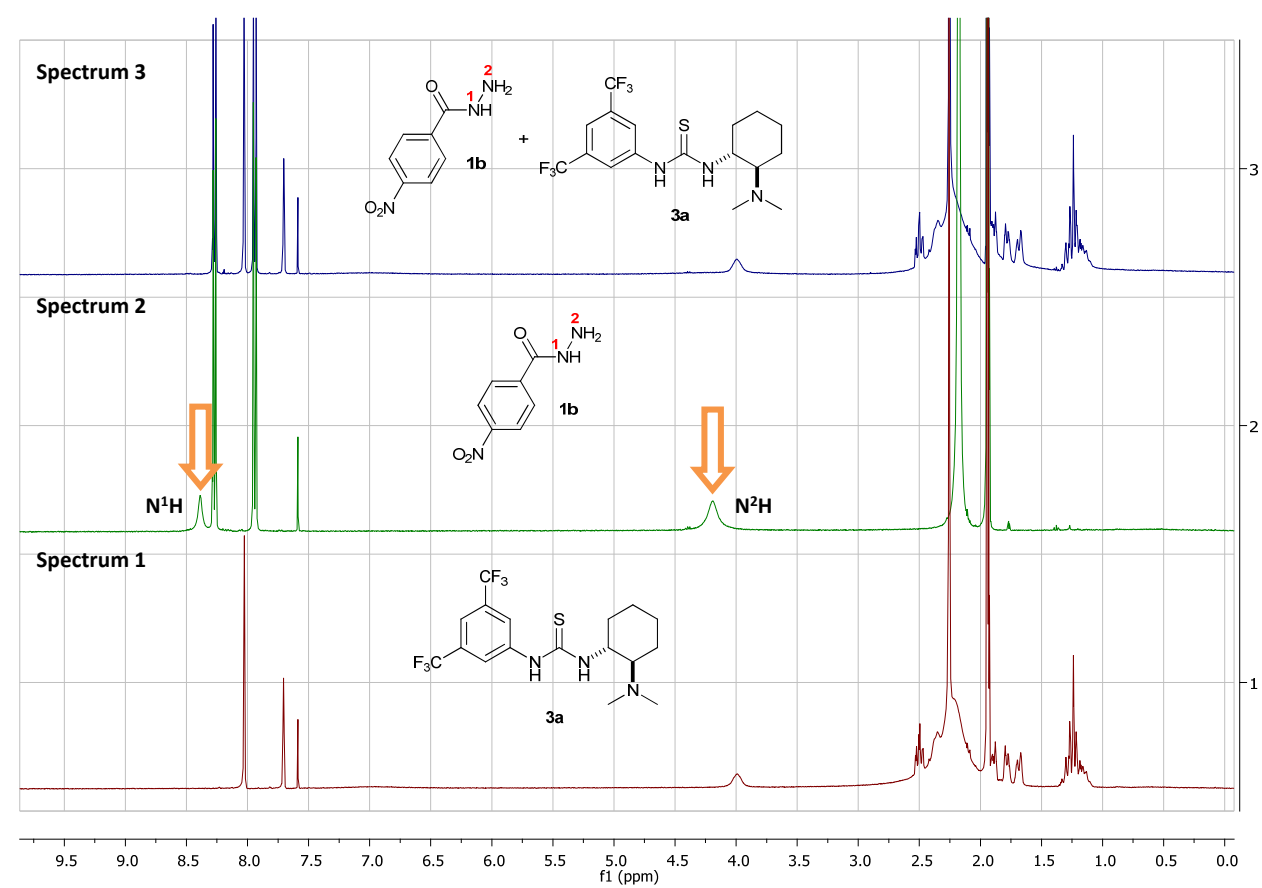

Fig. $4{ }^{1} \mathrm{H}-\mathrm{NMR}$ experiments performed in $\mathrm{CD}_{3} \mathrm{CN}$ with thiourea $\mathbf{3 a}$ and hydrazide $\mathbf{1 b}(400 \mathrm{MHz})$. 


\section{ARTICLE}

Additionally, in order to discard the attribution of this interaction to the thiourea group, we repeated the same experiments with thiourea $\mathbf{3} \mathbf{f}^{29}$ without the basic moiety (Figure 5). In this case, in the experiment using a mixture of thiourea $\mathbf{3 f}$ and hydrazide 1b (Figure 5, spectrum 3), the signals belonging to the $\mathrm{NH}$ groups of the hydrazide remained unaltered.

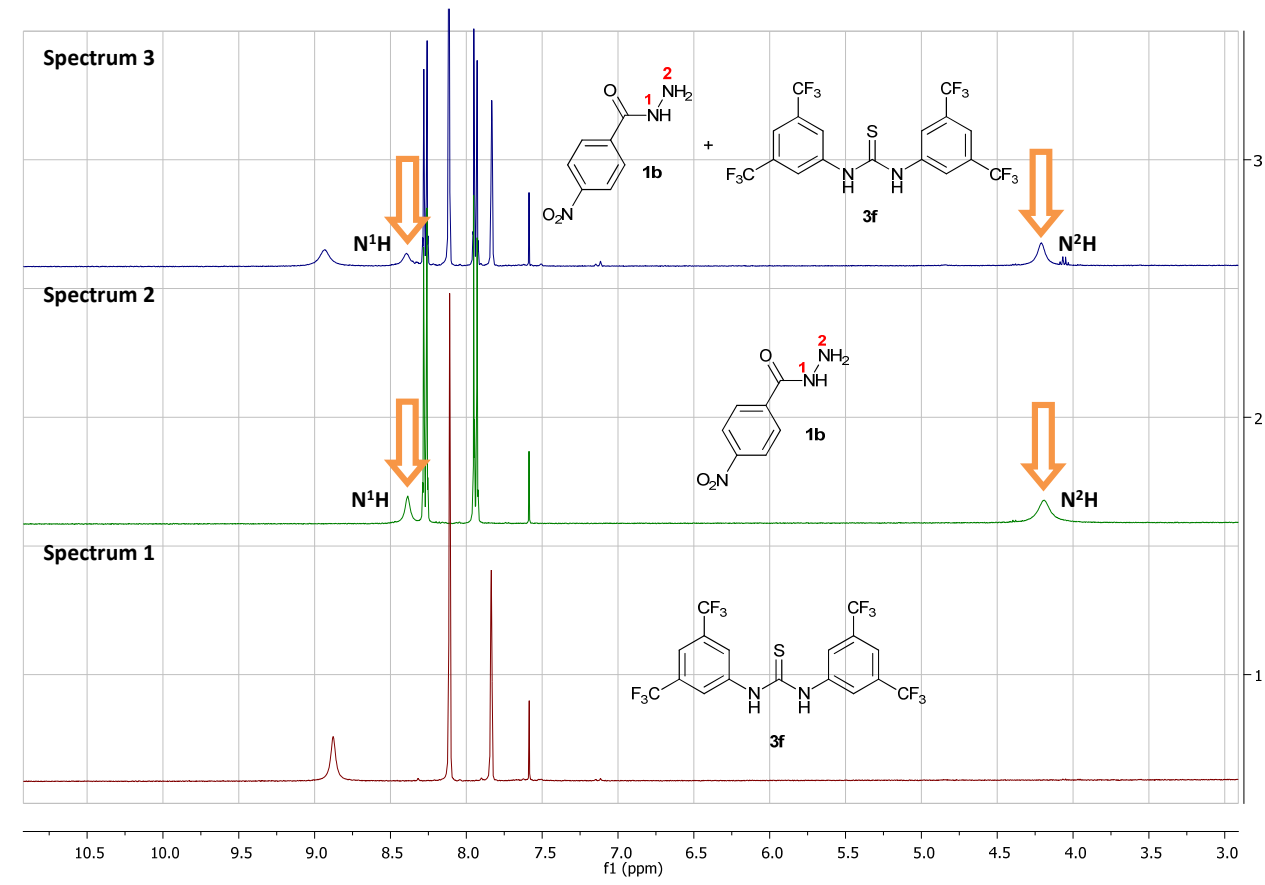

Fig. $5{ }^{1} \mathrm{H}$-NMR experiments performed in $\mathrm{CD}_{3} \mathrm{CN}$ with thiourea $\mathbf{3 f}$ and hydrazide $\mathbf{1 b}(400 \mathrm{MHz})$.

We have also performed the same experiments in the presence of an external base (Figure 6). By similitude with the basic moiety in the thiourea $3 \mathbf{a}$ we chose $\mathrm{Et}_{3} \mathrm{~N}$ for such a purpose. After to repeat the same NMR experiment for each species, we observed that the signals belonging to the $\mathrm{NH}$ groups of the hydrazide disappeared as a consequence of their interaction with the $\mathrm{Et}_{3} \mathrm{~N}$, as hypothesised. We envision that the same interaction should occur in our catalyst 3a. This outcome would also be in agreement with our proposed mechanism and will support the TS depicted in Figure 3. 


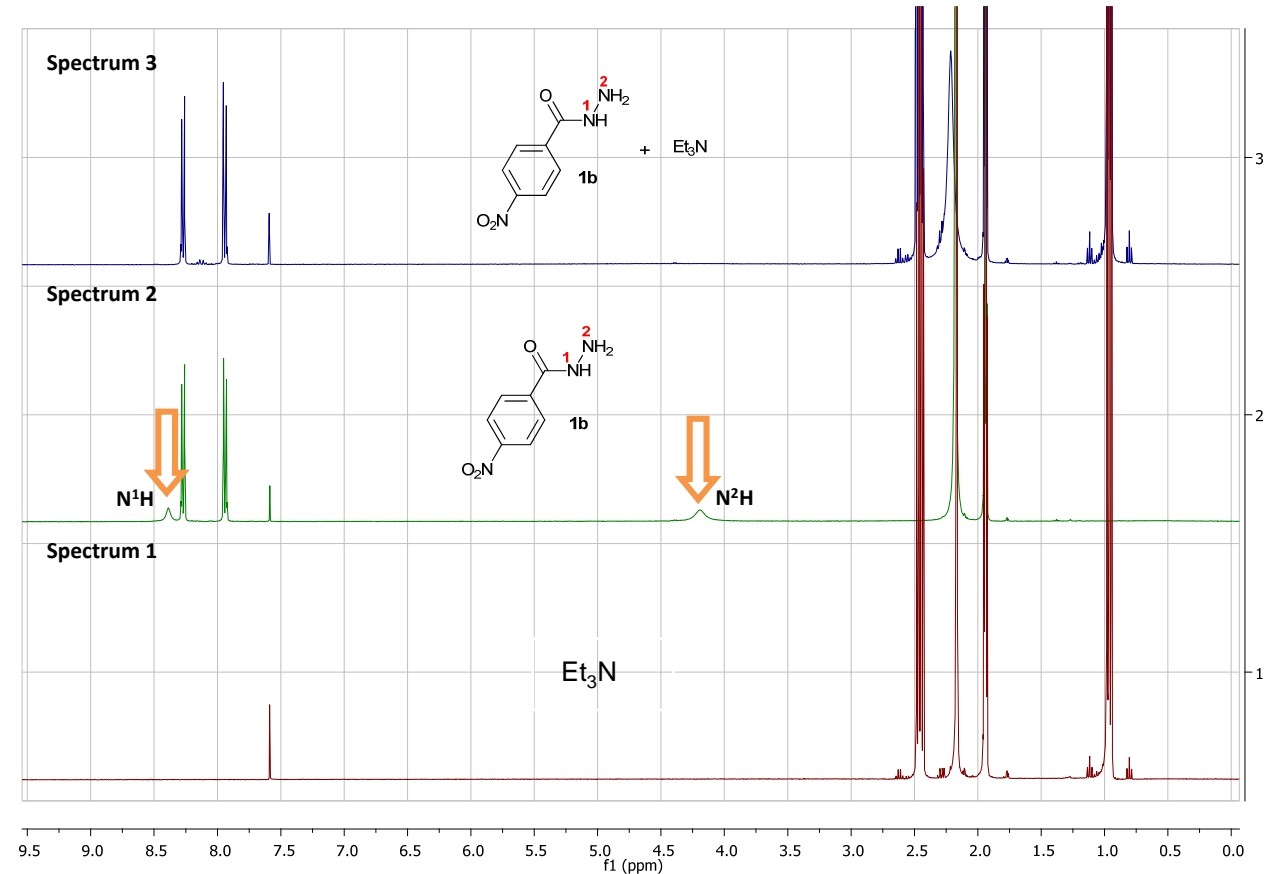

Fig. $6{ }^{1} \mathrm{H}$-NMR experiments performed in $\mathrm{CD}_{3} \mathrm{CN}$ with $\mathrm{Et}_{3} \mathrm{~N}$ and hydrazide $\mathbf{1 b}(400 \mathrm{MHz}$ )

All these facts could be also in agreement with our initial proposed hypothesis and the aforementioned TS concerning a plausible interaction between the basic moiety in the catalyst and the hydrazide, which would help to drive the enantioselective attack over the nitroalkene favouring a more rigid transition state. According to this theory, chiral thioureas in absence of a basic scaffold in their structures afforded poorer results in terms of both, reactivity and enantioselectivity (see supporting information for more experiments) (Figure 7).<smiles>FC(F)(F)c1cc(NC(=S)Nc2ccc3ccccc3c2-c2c(NC(=S)Nc3cccc4ccccc34)cc(C(F)(F)F)c3ccccc23)cc(C(F)(F)F)c1</smiles><smiles>OC1Cc2ccccc2C1NC(=S)Nc1cc(C(F)(F)F)cc(C(F)(F)F)c1</smiles>

Fig. 7 Thioureas $3 \mathbf{g}^{30} \mathbf{3 h},{ }^{31} \mathbf{3 i} \mathbf{i}^{14 b}$ explored in absence of the basic moiety in their structures. (Reaction conditions: to a solution of thiourea $3 \mathrm{~g}$-i $(20 \mathrm{~mol} \%)$ and nitrostyrene 2a $(0.1 \mathrm{mmol})$ in $\mathrm{CH}_{3} \mathrm{CN}(0.5 \mathrm{~mL})$, hydrazide $\mathbf{1 b}(0.1 \mathrm{mmol})$ was added at room temperature)

\section{Conclusions}

In summary, we have reported an unprecedented approach of thiourea-catalysed aza-Michael addition reaction of hydrazides to nitroalkenes providing easy access to inspiring building blocks with biological activity. ${ }^{1}$ This work could be a pivotal precedent in this area of research due to the difficulties to design new nitrogen nucleophiles with high activity, and in addition, this is one of the scarce examples where nitroalkenes ${ }^{32}$ and chiral thiourea catalysts ${ }^{18 b, 32 e, d, g, 33}$ have been used in asymmetric organocatalytic aza-Michael addition reactions. Further studies are being carried out in order to understand the role of the catalyst in this reaction and to clarify the function of the basic moiety of the catalyst and its possible coordination with the hydrazide. ${ }^{34,35}$ Moreover, studies applying these hydrazides in different Michael addition reactions are actively on-going in our laboratory.

\section{Experimental Section}

Representative procedure for thiourea organocatalysed azaMichael reaction of hydrazides to nitroalkenes

To a solution of thiourea 3a $(0.01$ or $0.02 \mathrm{mmol})$ and nitroalkenes $2 \mathrm{a}-\mathrm{l}(0.1 \mathrm{mmol})$ in $\mathrm{CH}_{3} \mathrm{CN}(0.25,0.5$ or $1 \mathrm{~mL})$, hydrazide $1 \mathbf{b}(0.1 \mathrm{mmol})$ was added in a test tube at $-27^{\circ} \mathrm{C}$ (or $-35^{\circ} \mathrm{C}$ ). After the corresponding reaction time (see Table 2), the residue was purified by flash chromatography $\left(\mathrm{SiO}_{2}\right.$, hexane/EtOAc 7:3) to afford final adducts 4. Yields and enantiomeric ratios are reported in Table 2. 
(S)-4-Nitro- $N$ '-(2-nitro-1-phenylethyl)benzohydrazide (4ba) Compound $4 \mathrm{ba}$ was obtained as a white solid after $84 \mathrm{~h}$ of reaction at $-27{ }^{\circ} \mathrm{C}$ in $>95 \%$ yield $(32 \mathrm{mg})$. M.p. $134-136{ }^{\circ} \mathrm{C}$. The er of the product was determined by HPLC using a Daicel Chiralpak IC column ( $n$-hexane/EtOAc $=80: 20$, flow rate 1 $\mathrm{mL} / \mathrm{min}, \lambda=258.8 \mathrm{~nm}): \mathrm{t}_{\text {major }}=13.8 \mathrm{~min} ; \mathrm{t}_{\text {minor }}=16.8 \mathrm{~min}$. $[\alpha]_{\mathrm{D}}{ }^{24}=+19.3(c=0.20$, acetone, $88: 12 \mathrm{er}) .{ }^{1} \mathrm{H}$ NMR $(400$ $\left.\mathrm{MHz}, \mathrm{CD}_{2} \mathrm{Cl}_{2}\right) \delta$ 8.24-8.27 (m, 2H), 7.78-7.81 (m, 2H), 7.60$7.61(\mathrm{~m}, 1 \mathrm{H}, \mathrm{NH}), 7.40-7.46(\mathrm{~m}, 5 \mathrm{H}), 5.41(\mathrm{dd}, J=2.8,5.7 \mathrm{~Hz}$, $1 \mathrm{H}, \mathrm{NH}), 4.95$ (ddd, $J=2.8,4.3,8.6 \mathrm{~Hz}, 1 \mathrm{H}), 4.84(\mathrm{dd}, J=8.6$, $12.7 \mathrm{~Hz}, 1 \mathrm{H}), 4.66(\mathrm{dd}, J=4.3,12.7 \mathrm{~Hz}, 1 \mathrm{H}) .{ }^{13} \mathrm{C}$ NMR $(100$ $\left.\mathrm{MHz}, \mathrm{CD}_{2} \mathrm{Cl}_{2}\right) \delta 166.4(1 \mathrm{C}), 150.3(1 \mathrm{C}), 138.3(1 \mathrm{C}), 136.4$ (1C), 129.6 (1C), 129.5 (2C), 128.6 (2C), 128.0 (2C), 124.3 (2C), 79.6 (1C), 62.5 (1C). IR (KBr film) $\left(\mathrm{cm}^{-1}\right)$ v 3277, 2924, 2854, 1621, 1593, 1561, 1537, 1524, 1456, 1426, 1376, 1345, 1313, 1299, 719, 701, 690. HRMS (ESI+) calcd $\mathrm{C}_{15} \mathrm{H}_{14} \mathrm{~N}_{4} \mathrm{NaO}_{5}$ 353.0856; found $353.0865\left[\mathrm{M}^{+}+\mathrm{Na}\right]$.

\section{(S)-N'-(1-(4-Fluorophenyl)-2-nitroethyl)-4-}

\section{nitrobenzohydrazide (4bb)}

Compound $\mathbf{4 b b}$ was obtained as an orange solid after $72 \mathrm{~h}$ of reaction at $-27{ }^{\circ} \mathrm{C}$ in $53 \%$ yield $(18.4 \mathrm{mg})$. M.p. $165-167{ }^{\circ} \mathrm{C}$. The er of the product was determined by HPLC using a Daicel Chiralpak IC column ( $n$-hexane/EtOAc $=80: 20$, flow rate 1 $\mathrm{mL} / \mathrm{min}, \lambda=260.0 \mathrm{~nm}): \mathrm{t}_{\text {major }}=13.1 \mathrm{~min} ; \mathrm{t}_{\text {minor }}=15.9 \mathrm{~min}$. $[\alpha]_{\mathrm{D}}{ }^{25}=+18.0\left(c=0.94\right.$, acetone, $88: 12$ er). ${ }^{1} \mathrm{H}$ NMR (400 $\left.\mathrm{MHz}, \mathrm{CD}_{3} \mathrm{COCD}_{3}\right) \delta 9.68$ (br s, $\left.1 \mathrm{H}, \mathrm{NH}\right), 8.28-8.32(\mathrm{~m}, 2 \mathrm{H})$, 8.01-8.04 (m, 2H), 7.57-7.60 (m, 2H), 7.12-7.18 (m, 2H), 5.70 (br s, 1H, NH), $5.11(\mathrm{dd}, J=7.4,12.8 \mathrm{~Hz}, 1 \mathrm{H}), 4.97-5.00(\mathrm{~m}$, $1 \mathrm{H}), 4.86(\mathrm{dd}, J=6.0,12.8 \mathrm{~Hz}, 1 \mathrm{H}) .{ }^{13} \mathrm{C} \mathrm{NMR}(100 \mathrm{MHz}$, $\left.\mathrm{CD}_{3} \mathrm{COCD}_{3}\right) \delta 167.1(1 \mathrm{C}), 164.7(\mathrm{~d}, J=245.0 \mathrm{~Hz}, 1 \mathrm{C}), 151.6$ (1C), 140.5 (1C), $135.2(\mathrm{~m}, 1 \mathrm{C}), 132.0(\mathrm{~d}, J=8.4 \mathrm{~Hz}, 2 \mathrm{C})$, 130.5 (2C), 125.4 (2C), 117.2 (d, $J=21.6 \mathrm{~Hz}, 2 \mathrm{C}), 80.3$ (1C), 63.1 (1C). IR (KBr film) $\left(\mathrm{cm}^{-1}\right) \vee 3261,2924,2854,1631$, 1597, 1554, 1510, 1462, 1427, 1378, 1344, 1317, 1224, 1192, $1124,1105,963,887,864,849,831,818,690$. HRMS (ESI+) calcd $\mathrm{C}_{15} \mathrm{H}_{13} \mathrm{FN}_{4} \mathrm{NaO}_{5}$ 371.0762; found $371.0742\left[\mathrm{M}^{+}+\mathrm{Na}\right]$.

\section{(S)-N'-(1-(4-Chlorophenyl)-2-nitroethyl)-4-}

\section{nitrobenzohydrazide (4bc)}

Compound 4 bc was obtained as an orange solid after $72 \mathrm{~h}$ of reaction at $-27{ }^{\circ} \mathrm{C}$ in $82 \%$ yield $(29,9 \mathrm{mg})$. M.p. $146-148{ }^{\circ} \mathrm{C}$. The er of the product was determined by HPLC using a Daicel Chiralpak IC column $(n$-hexane/EtOAc $=80: 20$, flow rate 1 $\mathrm{mL} / \mathrm{min}, \lambda=258.8 \mathrm{~nm}): \mathrm{t}_{\text {major }}=13.5 \mathrm{~min} ; \mathrm{t}_{\text {minor }}=16.4 \mathrm{~min}$. $[\alpha]_{\mathrm{D}}^{25}=+20.3(c=0.24$, acetone, $80: 20 \mathrm{er}) .{ }^{1} \mathrm{H}$ NMR $(400$ $\left.\mathrm{MHz}, \mathrm{CD}_{2} \mathrm{Cl}_{2}\right) \delta$ 8.25-8.28 (m, 2H), 7.79-7.82 (m, 2H), 7.58$7.59(\mathrm{~m}, 1 \mathrm{H}, \mathrm{NH}), 7.41(\mathrm{~s}, 4 \mathrm{H}), 5.38(\mathrm{dd}, J=2.9,5.7 \mathrm{~Hz}, 1 \mathrm{H}$, NH), 4.93-4.97 (m, 1H), 4.81 (dd, $J=8.4,12.8 \mathrm{~Hz}, 1 \mathrm{H}), 4.63$ $(\mathrm{dd}, J=4.5,12.8 \mathrm{~Hz}, 1 \mathrm{H}) .{ }^{13} \mathrm{C}$ NMR $\left(100 \mathrm{MHz}, \mathrm{CD}_{2} \mathrm{Cl}_{2}\right) \delta$ 166.5 (1C), 150.4 (1C), 138.1 (1C), 135.4 (1C), 135.0 (1C), 129.7 (2C), 129.5 (2C), 128.6 (2C), 124.3 (2C), 79.3 (1C), 61.8 (1C). IR (KBr film) $\left(\mathrm{cm}^{-1}\right)$ v 3274, 2924, 2854, 1733, 1674, $1653,1603,1558,1520,1491,1378,1342,1259,1175,1138$, 1090, 1068, 1015, 868, 850. HRMS (ESI+) calcd $\mathrm{C}_{15} \mathrm{H}_{13} \mathrm{ClN}_{4} \mathrm{NaO}_{5}$ 387.0467; found $387.0488\left[\mathrm{M}^{+}+\mathrm{Na}\right]$.
(S)-N'-(1-(4-Bromophenyl)-2-nitroethyl)-4nitrobenzohydrazide (4bd)

Compound 4bd was obtained as a yellow solid after $96 \mathrm{~h}$ of reaction at $-27{ }^{\circ} \mathrm{C}$ in $86 \%$ yield $(35.2 \mathrm{mg})$. M.p. $152-154{ }^{\circ} \mathrm{C}$. The er of the product was determined by HPLC using a Daicel Chiralpak IC column ( $n$-hexane/EtOAc $=80: 20$, flow rate 1 $\mathrm{mL} / \mathrm{min}, \lambda=258.8 \mathrm{~nm}): \mathrm{t}_{\text {major }}=13.3 \mathrm{~min} ; \mathrm{t}_{\text {minor }}=16.1 \mathrm{~min}$. $[\alpha]_{\mathrm{D}}{ }^{25}=+22.9\left(c=0.69\right.$, acetone, $82: 18$ er). ${ }^{1} \mathrm{H}$ NMR (400 $\left.\mathrm{MHz}, \mathrm{CD}_{3} \mathrm{COCD}_{3}\right) \delta 9.56$ (br s, $\left.1 \mathrm{H}, \mathrm{NH}\right), 8.15-8.17(\mathrm{~m}, 2 \mathrm{H})$, 7.88-7.90 (m, 2H), 7.42-7.45 (m, 2H), 7.36-7.38 (m, 2H), 5.62 (br s, 1H, NH), 4.97 (dd, $J=7.3,12.9 \mathrm{~Hz}, 1 \mathrm{H}), 4.83-4.87$ (br m, $1 \mathrm{H}, \mathrm{NH}), 4.74(\mathrm{dd}, J=5.9,12.9 \mathrm{~Hz}, 1 \mathrm{H}) .{ }^{13} \mathrm{C} \mathrm{NMR}(100 \mathrm{MHz}$, $\left.\mathrm{CD}_{3} \mathrm{COCD}_{3}\right) \delta 167.0(1 \mathrm{C}), 151.6$ (1C), 140.5 (1C), 138.5 (1C), 133.5 (2C), 132.1 (2C), 130.5 (2C), 125.4 (2C), 123.9 (1C), 80.0 (1C), 63.2 (1C). IR ( $\mathrm{KBr}$ film) $\left(\mathrm{cm}^{-1}\right)$ v 3314, 2924, 2854, 1646, 1597, 1543, 1522, 1460, 1376, 1350, 1306, 1073, 1011, 876, 849, 828, 772, 724. HRMS (ESI+) calcd $\mathrm{C}_{15} \mathrm{H}_{13} \mathrm{BrN}_{4} \mathrm{NaO}_{5}$ 430.9962; found $430.9947\left[\mathrm{M}^{+}+\mathrm{Na}\right]$.

\section{(S)-N'-(1-(3,4-Dichlorophenyl)-2-nitroethyl)-4- nitrobenzohydrazide (4be)}

Compound 4be was obtained as an orange solid after $72 \mathrm{~h}$ of reaction at $-27^{\circ} \mathrm{C}$ in $88 \%$ yield $(35.1 \mathrm{mg})$. M.p. $70-75^{\circ} \mathrm{C}$. The er of the product was determined by HPLC using a Daicel Chiralpak IC column ( $n$-hexane/EtOAc $=80: 20$, flow rate 1 $\mathrm{mL} / \mathrm{min}, \lambda=258.8 \mathrm{~nm}): \mathrm{t}_{\text {major }}=11.9 \mathrm{~min} ; \mathrm{t}_{\text {minor }}=14.2 \mathrm{~min}$. $[\alpha]_{\mathrm{D}}{ }^{25}=+35.8\left(c=0.35, \mathrm{CHCl}_{3}, 83: 17\right.$ er $) .{ }^{1} \mathrm{H}$ NMR $(400 \mathrm{MHz}$,

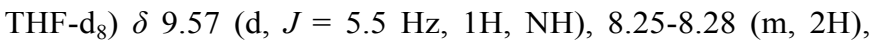
7.90-7.93 (m, 2H), $7.74(\mathrm{~d}, J=2.0 \mathrm{~Hz}, 1 \mathrm{H}), 7.53(\mathrm{~d}, J=8.3 \mathrm{~Hz}$, $1 \mathrm{H}), 7.43(\mathrm{dd}, J=2.0,8.3 \mathrm{~Hz}, 1 \mathrm{H}), 5.84(\mathrm{dd}, J=3.7,5.5 \mathrm{~Hz}$, $1 \mathrm{H}, \mathrm{NH}), 4.91(\mathrm{~m}, 2 \mathrm{H}), 4.74-4.80(\mathrm{~m}, 1 \mathrm{H}) .{ }^{13} \mathrm{C}$ NMR $(100$ MHz, THF-d 8 ) $\delta 166.4$ (1C), 150.8 (1C), 139.6 (1C), 139.5 (1C), 133.2 (1C), 133.0 (1C), 131.4 (1C), 131.1 (1C), 129.3 (2C), 129.0 (1C), 124.2 (2C), 78.8 (1C), 61.9 (1C). IR ( $\mathrm{KBr}$ film) $\left(\mathrm{cm}^{-1}\right) \vee 3286,3108,2959,2927,2857,1659,1601,1554$, 1526, 1469, 1377, 1346, 1299, 1198, 1134, 1111, 1076, 1032, $1014,952,868,850,826,718,683$. HRMS (ESI+) calcd $\mathrm{C}_{15} \mathrm{H}_{13} \mathrm{Cl}_{2} \mathrm{~N}_{4} \mathrm{O}_{5}$ 399.0258; found $399.0234\left[\mathrm{M}^{+}+\mathrm{H}\right]$.

\section{(S)-N'-(1-(4-Methoxyphenyl)-2-nitroethyl)-4- nitrobenzohydrazide (4bf)}

Compound $4 \mathbf{b f}$ was obtained as a yellow solid after $120 \mathrm{~h}$ of reaction at $-27{ }^{\circ} \mathrm{C}$ in $83 \%$ yield $(29.9 \mathrm{mg})$. M.p. $109-111^{\circ} \mathrm{C}$. The er of the product was determined by HPLC using a Daicel Chiralpak IC column ( $n$-hexane/EtOAc $=80: 20$, flow rate 1 $\mathrm{mL} / \mathrm{min}, \lambda=260.0 \mathrm{~nm}): \mathrm{t}_{\text {major }}=21.4 \mathrm{~min} ; \mathrm{t}_{\text {minor }}=27.7 \mathrm{~min}$. $[\alpha]_{\mathrm{D}}{ }^{25}=+21.8(c=0.63$, acetone, $78: 22 \mathrm{er}) .{ }^{1} \mathrm{H}$ NMR $(400$ $\left.\mathrm{MHz}, \mathrm{CDCl}_{3}\right) \delta 8.24-8.27(\mathrm{~m}, 2 \mathrm{H}), 7.78-7.81(\mathrm{~m}, 2 \mathrm{H}), 7.73-$ $7.74(\mathrm{~m}, 1 \mathrm{H}, \mathrm{NH}), 7.31-7.34(\mathrm{~m}, 2 \mathrm{H}), 6.90-6.93(\mathrm{~m}, 2 \mathrm{H}), 5.31-$ $5.33(\mathrm{~m}, 1 \mathrm{H}, \mathrm{NH}), 4.89-4.93(\mathrm{~m}, 1 \mathrm{H}), 4.79(\mathrm{dd}, J=8.9,12.4$ $\mathrm{Hz}, 1 \mathrm{H}), 4.58(\mathrm{dd}, J=4.0,12.4 \mathrm{~Hz}, 1 \mathrm{H}), 3.81(\mathrm{~s}, 3 \mathrm{H}) .{ }^{13} \mathrm{C} \mathrm{NMR}$ $\left(75 \mathrm{MHz}, \mathrm{CDCl}_{3}\right) \delta 166.1$ (1C), 160.2 (1C), 149.9 (1C), 137.7 (1C), 128.8 (2C), 128.2 (2C), 127.5 (1C), 124.0 (2C), 114.6 (2C), 79.7 (1C), 61.7 (1C), 55.3 (1C). IR ( KBr film) $\left(\mathrm{cm}^{-1}\right) v$ 3287, 3110, 2924, 2854, 1663, 1603, 1547, 1515, 1463, 1377, 
$1348,1306,1279,1253,1178,1134,1112,1027,868,851$, 834, 719, 683. HRMS (ESI+) calcd $\mathrm{C}_{16} \mathrm{H}_{16} \mathrm{~N}_{4} \mathrm{NaO}_{6}$ 383.0962; found $383.0942\left[\mathrm{M}^{+}+\mathrm{Na}\right]$.

\section{(S)-N'-(1-(2-Methoxyphenyl)-2-nitroethyl)-4-}

\section{nitrobenzohydrazide (4bg)}

Compound $4 \mathbf{b g}$ was obtained as a yellow solid after $120 \mathrm{~h}$ of reaction at $-27{ }^{\circ} \mathrm{C}$ in $72 \%$ yield $(25.9 \mathrm{mg})$. M.p. $134-137{ }^{\circ} \mathrm{C}$. The er of the product was determined by HPLC using a Daicel Chiralpak IC column ( $n$-hexane/EtOAc $=80: 20$, flow rate 1 $\mathrm{mL} / \mathrm{min}, \lambda=262.4 \mathrm{~nm}): \mathrm{t}_{\text {major }}=17.2 \mathrm{~min} ; \mathrm{t}_{\text {minor }}=24.2 \mathrm{~min}$. $[\alpha]_{\mathrm{D}}{ }^{25}=+15.2\left(c=0.63\right.$, acetone, 83:17 er). ${ }^{1} \mathrm{H}$ NMR $(400$ $\left.\mathrm{MHz}, \mathrm{CDCl}_{3}\right) \delta 8.25-8.28(\mathrm{~m}, 2 \mathrm{H}), 7.80-7.83(\mathrm{~m}, 2 \mathrm{H}), 7.64(\mathrm{br}$ $\mathrm{d}, J=4.7 \mathrm{~Hz}, 1 \mathrm{H}, \mathrm{NH}), 7.33-7.37(\mathrm{~m}, 2 \mathrm{H}), 6.94-7.00(\mathrm{~m}, 2 \mathrm{H})$, $5.77($ br s, $1 \mathrm{H}, \mathrm{NH}), 5.09-5.13(\mathrm{~m}, 1 \mathrm{H}), 4.88(\mathrm{dd}, J=8.7,12.6$ $\mathrm{Hz}, 1 \mathrm{H}), 4.68(\mathrm{dd}, J=4.0,12.6 \mathrm{~Hz}, 1 \mathrm{H}), 3.91(\mathrm{~s}, 3 \mathrm{H}) .{ }^{13} \mathrm{C} \mathrm{NMR}$ $\left(75 \mathrm{MHz}, \mathrm{CDCl}_{3}\right) \delta 165.6$ (1C), 157.1 (1C), 149.7 (1C), 137.8 (1C), 130.2 (1C), 128.5 (1C), 128.2 (2C), 123.8 (2C), 123.6 (1C), 120.9 (1C), 111.0 (1C), 77.8 (1C), 59.1 (1C), 55.5 (1C). IR $(\mathrm{KBr}$ film $)\left(\mathrm{cm}^{-1}\right) \vee 3289,3266,2925,2866,1648,1598$, $1537,1523,1489,1464,1374,1342,1324,1241,1110,869$, 848, 764. HRMS (ESI+) calcd $\mathrm{C}_{16} \mathrm{H}_{16} \mathrm{~N}_{4} \mathrm{NaO}_{6} 383.0962$; found $383.0941\left[\mathrm{M}^{+}+\mathrm{Na}\right]$

\section{(S)-4-Nitro-N'-(2-nitro-1-(p-tolyl)ethyl)benzohydrazide (4bh)}

Compound 4bh was obtained as a yellow solid after $96 \mathrm{~h}$ of reaction at $-27{ }^{\circ} \mathrm{C}$ in $62 \%$ yield $(21.3 \mathrm{mg})$. M.p. $100-102{ }^{\circ} \mathrm{C}$. The er of the product was determined by HPLC using a Daicel Chiralpak IC column ( $n$-hexane/EtOAc $=80: 20$, flow rate 1 $\mathrm{mL} / \mathrm{min}, \lambda=260.0 \mathrm{~nm}): \mathrm{t}_{\text {major }}=15.9 \mathrm{~min} ; \mathrm{t}_{\text {minor }}=19.4 \mathrm{~min}$. $[\alpha]_{\mathrm{D}}{ }^{24}=+24.5(c=0.81$, acetone, $78: 22 \mathrm{er}) .{ }^{1} \mathrm{H}$ NMR $(400$ MHz, THF-d 8 ) $\delta 9.53$ (br d, $J=5.7 \mathrm{~Hz}, 1 \mathrm{H}, \mathrm{NH}), 8.26$ (d, $J=$ $8.9 \mathrm{~Hz}, 2 \mathrm{H}), 7.92(\mathrm{~d}, J=8.9 \mathrm{~Hz}, 2 \mathrm{H}), 7.35(\mathrm{~d}, J=8.0 \mathrm{~Hz}, 2 \mathrm{H})$, $7.16(\mathrm{~d}, J=7.9 \mathrm{~Hz}, 2 \mathrm{H}), 5.63(\mathrm{dd}, J=3.6,5.7 \mathrm{~Hz}, 1 \mathrm{H}, \mathrm{NH})$, 4.86-4.94 (m, 2H), 4.66-4.75 (m, 1H), $2.31(\mathrm{~s}, 3 \mathrm{H}) .{ }^{13} \mathrm{C} \mathrm{NMR}$ $\left(100 \mathrm{MHz}, \mathrm{THF}-\mathrm{d}_{8}\right) \delta 166.2$ (1C), 150.7 (1C), 139.9 (1C), 139.0 (1C), 135.5 (1C), 130.0 (2C), 129.3 (2C), 128.7 (2C), 124.2 (2C), 79.7 (1C), 62.8 (1C), 21.2 (1C). IR (KBr film) (cm 1) $v 3263,2924,2855,1651,1600,1548,1526,1459,1422$, 1378, 1346, 1307, 1224, 896, 873, 850, 822, 791, 778, 722, 695. HRMS (ESI+) calcd $\mathrm{C}_{16} \mathrm{H}_{16} \mathrm{~N}_{4} \mathrm{NaO}_{5}$ 367.1013; found $367.1003\left[\mathrm{M}^{+}+\mathrm{Na}\right]$

\section{(S)-N'-(1-(4-(Benzyloxy)phenyl)-2-nitroethyl)-4-} nitrobenzohydrazide (4bi)

Compound 4bi was obtained as a yellow solid after $120 \mathrm{~h}$ of reaction at $-27{ }^{\circ} \mathrm{C}$ in $42 \%$ yield $(18.3 \mathrm{mg})$. M.p. $149-151^{\circ} \mathrm{C}$. The er of the product was determined by HPLC using a Daicel Chiralpak IC column ( $n$-hexane/EtOAc $=80: 20$, flow rate 1 $\mathrm{mL} / \mathrm{min}, \lambda=260.0 \mathrm{~nm}): \mathrm{t}_{\text {major }}=19.9 \mathrm{~min} ; \mathrm{t}_{\text {minor }}=26.1 \mathrm{~min}$. $[\alpha]_{\mathrm{D}}{ }^{25}=+27.1(c=0.36$, acetone, $85: 15 \mathrm{er}) .{ }^{1} \mathrm{H}$ NMR $(400$ $\left.\mathrm{MHz}, \mathrm{CDCl}_{3}\right) \delta 8.27-8.30(\mathrm{~m}, 2 \mathrm{H}), 7.78-7.81(\mathrm{~m}, 2 \mathrm{H}), 7.47(\mathrm{br}$ $\mathrm{s}, 1 \mathrm{H}, \mathrm{NH}), 7.33-7.47(\mathrm{~m}, 7 \mathrm{H}), 7.00-7.02(\mathrm{~m}, 2 \mathrm{H}), 5.31$ (br s, $1 \mathrm{H}, \mathrm{NH}), 5.08(\mathrm{~s}, 2 \mathrm{H}), 4.92(\mathrm{dd}, J=3.8,8.9 \mathrm{~Hz}, 1 \mathrm{H}), 4.80(\mathrm{dd}$, $J=9.0,12.3 \mathrm{~Hz}, 1 \mathrm{H}), 4.59(\mathrm{dd}, J=3.9,12.3 \mathrm{~Hz}, 1 \mathrm{H}) .{ }^{13} \mathrm{C} \mathrm{NMR}$ $\left(100 \mathrm{MHz}, \mathrm{CD}_{3} \mathrm{COCD}_{3}\right) \delta 167.0(1 \mathrm{C}), 161.0(1 \mathrm{C}), 151.6(1 \mathrm{C})$, 140.7 (1C), 140.6 (1C), 139.2 (1C), 131.1 (2C), 130.5 (2C), 130.3 (2C), 129.7 (1C), 129.5 (2C), 125.4 (2C), 116.7 (2C), 80.5 (1C), 71.4 (1C), 63.4 (1C). IR (KBr film) $\left(\mathrm{cm}^{-1}\right) \vee 3386$, 2924, 2854, 1650, 1603, 1553, 1538, 1513, 1465, 1377, 1344, $1327,1231,1178,1002,870,852,840,747,719,696$. HRMS (ESI+) calcd $\mathrm{C}_{22} \mathrm{H}_{20} \mathrm{~N}_{4} \mathrm{NaO}_{6} \quad 459.1275$; found 459.1254 $\left[\mathrm{M}^{+}+\mathrm{Na}\right]$.

\section{(S)-N'-(1-(Furan-2-yl)-2-nitroethyl)-4-nitrobenzohydrazide (4bj)}

Compound 4bj was obtained as an orange solid after $120 \mathrm{~h}$ of reaction at $-27{ }^{\circ} \mathrm{C}$ in $55 \%$ yield $(17.6 \mathrm{mg})$. M.p. $145-147{ }^{\circ} \mathrm{C}$. The er of the product was determined by HPLC using a Daicel Chiralpak IC column ( $n$-hexane/EtOAc $=80: 20$, flow rate 1 $\mathrm{mL} / \mathrm{min}, \lambda=258.8 \mathrm{~nm}): t_{\text {major }}=17.7 \mathrm{~min} ; \mathrm{t}_{\text {minor }}=19.7 \mathrm{~min}$. $[\alpha]_{\mathrm{D}}{ }^{24}=+28.8(c=0.34$, acetone, $92: 8 \mathrm{er}) .{ }^{1} \mathrm{H} \mathrm{NMR}(400 \mathrm{MHz}$, $\left.\mathrm{CD}_{2} \mathrm{Cl}_{2}\right) \delta 8.26-8.30(\mathrm{~m}, 2 \mathrm{H}), 7.83-7.86(\mathrm{~m}, 2 \mathrm{H}), 7.64$ (br d, $J=$ $5.9 \mathrm{~Hz}, 1 \mathrm{H}, \mathrm{NH}), 7.47$ (dd, $J=0.8,1.8 \mathrm{~Hz}, 1 \mathrm{H}), 6.40-6.43$ (m, $2 \mathrm{H}), 5.44-5.46(\mathrm{~m}, 1 \mathrm{H}, \mathrm{NH}), 5.00-5.05(\mathrm{~m}, 1 \mathrm{H}), 4.89(\mathrm{dd}, J=$ $8.4,13.3 \mathrm{~Hz}, 1 \mathrm{H}), 4.77(\mathrm{dd}, J=4.9,13.3 \mathrm{~Hz}, 1 \mathrm{H}) .{ }^{13} \mathrm{C} \mathrm{NMR}$ (75 MHz, THF-d 8 ) $\delta 166.0$ (1C), 151.4 (1C), 150.7 (1C), 143.8 (1C), 139.7 (1C), 129.3 (2C), 124.2 (2C), 111.1 (1C), 109.4 (1C), 76.7 (1C), 57.0 (1C). IR (KBr film) $\left(\mathrm{cm}^{-1}\right) \vee 3276,2922$, 2852, 1737, 1699, 1651, 1598, 1558, 1521, 1460, 1377, 1345, 1013. HRMS (ESI+) calcd $\mathrm{C}_{13} \mathrm{H}_{12} \mathrm{~N}_{4} \mathrm{NaO}_{6}$ 343.0649; found $343.0649\left[\mathrm{M}^{+}+\mathrm{Na}\right]$.

\section{(S)-N'-(1-Cyclohexyl-2-nitroethyl)-4-nitrobenzohydrazide (4bk)}

Compound 4bk was obtained as an orange solid after $72 \mathrm{~h}$ of reaction at $-27{ }^{\circ} \mathrm{C}$ in $40 \%$ yield $(13.4 \mathrm{mg})$. M.p. $91-93{ }^{\circ} \mathrm{C}$. The er of the product was determined by HPLC using a Daicel Chiralpak IC column ( $n$-hexane/EtOAc $=80: 20$, flow rate 1 $\mathrm{mL} / \mathrm{min}, \lambda=258.8 \mathrm{~nm}): \mathrm{t}_{\text {major }}=12.1 \mathrm{~min} ; \mathrm{t}_{\text {minor }}=16.8 \mathrm{~min}$. $[\alpha]_{\mathrm{D}}{ }^{25}=-11.1 \quad\left(c=0.12\right.$, acetone, 64:36 er). ${ }^{1} \mathrm{H}$ NMR $(400$ $\left.\mathrm{MHz}, \mathrm{CD}_{3} \mathrm{COCD}_{3}\right) \delta 9.63$ (br s, $\left.1 \mathrm{H}, \mathrm{NH}\right), 8.31-8.35(\mathrm{~m}, 2 \mathrm{H})$, 8.07-8.10 (m, 2H), 5.35-5.38 (m, $1 \mathrm{H}, \mathrm{NH}), 4.72(\mathrm{dd}, J=4.2$, $13.4 \mathrm{~Hz}, 1 \mathrm{H}), 4.63(\mathrm{dd}, J=7.7,13.4 \mathrm{~Hz}, 1 \mathrm{H}), 3.58-3.64(\mathrm{~m}$, $1 \mathrm{H}), 1.89-1.93(\mathrm{~m}, 2 \mathrm{H}), 1.65-1.80(\mathrm{~m}, 3 \mathrm{H}), 1.15-1.34(\mathrm{~m}, 6 \mathrm{H})$. ${ }^{13} \mathrm{C}$ NMR (100 MHz, $\left.\mathrm{CD}_{3} \mathrm{COCD}_{3}\right) \delta 167.0$ (1C), 151.6 (1C), 140.6 (1C), 130.5 (2C), 125.4 (2C), 78.3 (1C), 65.1 (1C), 40.8 (1C), 30.8 (2C), 30.2 (2C), 28.0 (1C). IR ( $\mathrm{KBr}$ film) $\left(\mathrm{cm}^{-1}\right) v$ 3295, 2927, 2854, 1658, 1601, 1552, 1526, 1451, 1347, 1300, $1109,1014,868,849,718$. HRMS (ESI+) calcd $\mathrm{C}_{15} \mathrm{H}_{20} \mathrm{~N}_{4} \mathrm{NaO}_{5}$ 359.1326; found $359.1313\left[\mathrm{M}^{+}+\mathrm{Na}\right]$.

\section{(S)-4-Nitro- $N$ '-(1-nitro-4-phenylbutan-2-yl)benzohydrazide (4bl)}

Compound $4 \mathrm{bl}$ was obtained as an orange solid after $120 \mathrm{~h}$ of reaction at $-35{ }^{\circ} \mathrm{C}$ in $47 \%$ yield $\left(16.8 \mathrm{mg}\right.$ ). M.p. $115-117^{\circ} \mathrm{C}$. The er of the product was determined by HPLC using a Daicel Chiralpak IC column ( $n$-hexane/EtOAc $=80: 20$, flow rate 1 $\mathrm{mL} / \mathrm{min}, \lambda=258.8 \mathrm{~nm}): \mathrm{t}_{\text {major }}=12.7 \mathrm{~min} ; \mathrm{t}_{\text {minor }}=14.4 \mathrm{~min}$. $[\alpha]_{\mathrm{D}}{ }^{25}=-10.5\left(c=0.31\right.$, acetone, 63:37 er). ${ }^{1} \mathrm{H}$ NMR (400 $\left.\mathrm{MHz}, \mathrm{CD}_{3} \mathrm{COCD}_{3}\right) \delta 9.65$ (br s, $\left.1 \mathrm{H}, \mathrm{NH}\right), 8.32-8.35(\mathrm{~m}, 2 \mathrm{H})$, 
8.11-8.14 (m, 2H), 7.27 (br d, $J=4.4 \mathrm{~Hz}, 4 \mathrm{H}), 7.16-7.21$ (m, $1 \mathrm{H}), 5.50-5.53$ (br m, $1 \mathrm{H}, \mathrm{NH}), 4.74(\mathrm{dd}, J=7.2,13.4 \mathrm{~Hz}, 1 \mathrm{H})$, $4.68(\mathrm{dd}, J=5.0,13.4 \mathrm{~Hz}, 1 \mathrm{H}), 3.74-3.81(\mathrm{~m}, 1 \mathrm{H}), 2.85-2.96$ $(\mathrm{m}, 2 \mathrm{H}), 1.96-2.09(\mathrm{~m}, 1 \mathrm{H}), 1.83-1.92(\mathrm{~m}, 1 \mathrm{H}) .{ }^{13} \mathrm{C}$ NMR $(75$ $\left.\mathrm{MHz}, \mathrm{CDCl}_{3}\right) \delta 166.3(1 \mathrm{C}), 150.0$ (1C), 140.4 (1C), 137.5 (1C), 128.7 (2C), 128.3 (2C), 128.2 (2C), 126.5 (1C), 124.0 (2C), 78.2 (1C), 58.5 (1C), 32.2 (1C), 31.9 (1C). IR (KBr film) $\left(\mathrm{cm}^{-}\right.$ $\left.{ }^{1}\right)$ v 3362, 3292, 3103, 3025, 3002, 2926, 2853, 1659, 1597, $1548,1519,1495,1470,1454,1414,1383,1352,1316,1297$, 1112, 1083, 1011, 910, 867, 847, 792, 754, 713, 696. HRMS (ESI+) calcd $\mathrm{C}_{17} \mathrm{H}_{18} \mathrm{~N}_{4} \mathrm{NaO}_{5} \quad 381.1169 ;$ found 381.1163 $\left[\mathrm{M}^{+}+\mathrm{Na}\right]$.

\section{Acknowledgements}

We thank the Spanish Ministry of Economía y Competitividad (MICINN. Madrid. Spain. Project CTQ2010-19606) and the Government of Aragón (Zaragoza. Spain. Research Group E10) for financial support of our research. We thank Dr. Pablo J. Sanz Miguel (ISQCH) and Prof. M. Concepción Gimeno (ISQCH) for X-ray structure analysis. We are also grateful to Prof. Luca Bernardi for his useful comments.

\section{Notes and references}

${ }^{a}$ Laboratorio de Síntesis Asimétrica, Departamento de Química Orgánica. Instituto de Síntesis Química y Catálisis Homogénea (ISQCH). CSICUniversidad de Zaragoza. E-50009 Zaragoza, Aragón, Spain Fax: +34 976762075. Phone: +34 976762281. E-mail: mmaamarq@unizar.es, raquelph@unizar.es

Electronic Supplementary Information (ESI) available: [details of any supplementary information available should be included here]. See DOI: $10.1039 / \mathrm{b} 000000 \mathrm{x} /$

1 a) R. E. Carnahan, Groton, R. E. Kent, Waterford, Conn, US Patent 2,865,923 filed July 2, 1954 and issued Dec. 23, 1958; b) J. L. Leighton, R. Berger, S. Shirakawa, G. T. Notte, US Patent 2008/0167468 A1, filed Jun 6, 2007 and issued Jul. 10, 2008.

2 For reviews about organocatalysed aza-Michael processes, see: a) J. L. Vicario, D. Badía and L. Carrillo, Synthesis, 2007, 2065; b) D. Enders, C. Wang and J. X. Liebich, Chem.-Eur. J., 2009, 15, 11058; c) J. Wang, P. Li, P. Y. Choy, A. S. C. Chan and F. Y. Kwong, Chem CatChem, 2012, 4, 917.

3 For reviews about metal catalysed aza-Michael reactions, see: a) L.W. Xu and C.-G. Xia, Eur. J. Org. Chem., 2005, 633; b) P. R. Krishna, A. Sreeshailam and R. Srinivas, Tetrahedron, 2009, 65, 9657.

4 For selected references, see for instances: a) G. Cardillo and C. Tomasini, Chem. Soc. Rev., 1996, 25, 117; b) S. G. Davies, A. D. Smith and P. D. Price, Tetrahedron: Asymmetry, 2005, 16, 2833; c) S. Chandrasekhar, N. R. Reddy and Y. S. Rao, Tetrahedron, 2006, 62, 12098; d) M. Dorbec, J.-C. Florent, C. Monneret, M.-N. Rager and E. Bertounesque, Tetrahedron, 2006, 62, 11766; e) M. Prakesch, S. Srivastava, D. M. Leek and P. Arya, J. Comb. Chem., 2006, 8, 762; f) M. Dorbec, J.-C. Florent, C. Monneret, M.-N. Rager and E. Bertounesque, Synlett, 2006, 591; g) M. Ihara, Chem. Pharm. Bull., 2006, 54, 765 .
5 For reviews about organocatalysed Michael addition reactions, see: a) S. Sulzer-Mossé and A. Alexakis, Chem. Commun., 2007, 3123; b) D. Almaşi, D. A. Alonso and C. Nájera, Tetrahedron: Asymmetry 2007, 18, 299; c) S. B. Tsogoeva, Eur. J. Org. Chem., 2007, 1701; d) D. Roca-López, D. Sadaba, I. Delso, R. P. Herrera, T. Tejero and P. Merino, Tetrahedron: Asymmetry, 2010, 21, 2561.

6 C. Nájera and J. M. Sansano, Chem. Rev., 2007, 107, 4584; and references therein cited.

7 B. Weiner, W. Szymański, D. B. Janssen, A. J. Minnaard and B. L. Feringa, Chem. Soc. Rev., 2010, 39, 1656; and references therein cited.

8 a) D. Lucet, T. Le Gall and C. Mioskowski, Angew. Chem. Int. Ed., 1998, 37, 2580; b) S. R. S. S. Kotti, C. Timmons and G. Li, Chem. Biol. Drug Des., 2006, 67, 101; c) H. Kim, S. M. So, J. Chin and B. M. Kim, Aldrichimica Acta, 2008, 41, 77.

9 a) B. Narasimhan, P. Kumar and D. Sharma, Acta Pharmaceutical Sciencia, 2010, 52, 169; b) R. Narang, B. Narasimhan and S. Sharma, Curr. Med. Chem., 2012, 19, 569.

10 For selected works of $\mathrm{N}^{1}$ addition, see for instance: a) Z. Wang, $\mathrm{T}$. Skerlj and G. J. Bridger, Tetrahedron Lett., 1999, 40, 3543; b) M. Wolter, A. Klapars and S. L. Buchwald, Org. Lett., 2001, 3, 3803; c) J. B. Arterburn, K. V. Rao, R. Ramdas and B. R. Dible, Org. Lett., 2001, 3, 1351; d) A. Nie and Z. Huang, J. Comb. Chem., 2006, 8, 655; e) J. Barluenga, P. Moriel, F. Aznar and C. Valdés, Org. Lett., 2007, 9, 275; f) M. P. Sibi and T. Soeta, J. Am. Chem. Soc., 2007, 129, 4522; g) M. S. Lam, H. W. Lee, A. S. C. Chan and F. Y. Kwong, Tetrahedron Lett., 2008, 49, 6192; h) J. M. de los Santos, Y. López, D. Aparicio and F. Palacios, J. Org. Chem., 2008, 73, 550; i) L. Jiang, X. Lu, H. Zhang, Y. Jiang and D. Ma, J. Org. Chem., 2009, 74, 4542; j) O. Mahé, D. Frath, I. Dez, F. Marsais, V. Levacher and J.-F. Brière, Org. Biomol. Chem., 2009, 7, 3648; k) J. L. Vicario and D. Badía, ChemCatChem., 2010, 2, 375; 1) V. Gembus, J.-J. Bonnet, F. Janin, P. Bohn, V. Levacher and J.-F. Brière, Org. Biomol. Chem., 2010, 8, 3287.

11 a) J. Gante, Synthesis, 1989, 405; b) E. Licandro and D. Perdicchia, Eur. J. Org. Chem., 2004, 665.

12 J. Jiang, Y. Cai, W. Chen, L. Lin, X. Liu and X. Feng, Chem. Commun., 2011, 47, 4016.

13 a) N. Ono (Ed.), The Nitro Group in Organic Synthesis, Wiley-VCH, New York, 2001; b) R. Ballini and M. Petrini, Tetrahedron, 2004, 60, 1017.

14 a) G. Dessole, R. P. Herrera and A. Ricci, Synlett, 2004, 2374; b) R. P. Herrera, V. Sgarzani, L. Bernardi and A. Ricci, Agew. Chem. Int. $E d$., 2005, 44, 6576; c) D. Pettersen, R. P. Herrera, L. Bernardi, F. Fini, V. Sgarzani, R. Fernández, J. M. Lassaletta and A. Ricci, Synlett, 2006, 239; d) A. Alcaine, E. Marqués-López, P. Merino, T. Tejero and R. P. Herrera, Org. Biomol. Chem., 2011, 9, 2777; e) E. Marqués-López, A. Alcaine, T. Tejero and R. P. Herrera, Eur. J. Org. Chem., 2011, 3700; f) E. Marqués-López and R. P. Herrera, in New Strategies in Chemical Synthesis and Catalysis, (Ed.: B. Pignataro) Wiley-VCH: Weinheim, 2012, pp 175-199.

15 a) P. R. Schreiner, Chem. Soc. Rev., 2003, 32, 289; b) Y. Takemoto, Org. Biomol. Chem., 2005, 3, 4299; c) S. J. Connon, Chem. Eur. J., 2006, 12, 5418; d) M. S. Taylor and E. N. Jacobsen, Angew. Chem. Int. Ed., 2006, 45, 1520; e) A. G. Doyle and E. N. Jacobsen, Chem. Rev., 2007, 107, 5713; f) Z. Zhang and P. R. Schreiner, Chem. Soc. 
Rev., 2009, 38, 1187; g) E. Marqués-López and R. P. Herrera, $A n$ Quim., 2009, 105, 5; h) M. Kotke and P. R. Schreiner, in Hydrogen Bonding in Organic Synthesis, (Ed.: P. M. Pihko), Wiley-VCH: Weinheim, 2009, pp 141-351; i) S. J. Connon, Synlett, 2009, 354.

16 a) L. Bernardi, F. Fini, R. P. Herrera, A. Ricci and V. Sgarzani, Tetrahedron, 2006, 62, 375; b) R. P. Herrera, D. Monge, E. MartínZamora, R. Fernández and J. M. Lassaletta, Org. Lett., 2007, 9, 3303.

17 For reviews about thioureas as bifunctional organocatalysts, see: a) H. Miyabe and Y. Takemoto, Bull. Chem. Soc. Jpn., 2008, 81, 785; b) S. J. Connon, Chem. Commun., 2008, 2499.

18 For proposals about related proton relay/shuttle systems, see: a) S. Okumoto and S. Yamabe, J. Org. Chem., 2000, 65, 1544; b) D Pettersen, F. Piana, L. Bernardi, F. Fini, M. Fochi, V. Sgarzani and A. Ricci, Tetrahedron Lett., 2007, 48, 7805.

19 T. Okino, Y. Hoashi and Y. Takemoto, J. Am. Chem. Soc., 2003, 125, 12672 .

20 B. M. Trost, Acc. Chem. Res., 2002, 35, 695.

21 Y. Zhu, J. P. Malerich and V. H. Rawal, Angew. Chem. Int. Ed., 2010, 49, 153

22 B. Vakula, S. Varga, A. Csámpai and T. Soós, Org. Lett., 2005, 7, 1967.

23 A. G. Wenzel and E. N. Jacobsen, J. Am. Chem. Soc., 2002, 124, 12964.

24 S. J. Zuend and E. N. Jacobsen, J. Am. Chem. Soc., 2007, 129, 15872.

25 For an example of $\pi$-stacking effect, see: A. Mazzanti, T. Calbet, M. Font-Bardia, A. Moyano and R. Rios, Org. Biomol. Chem., 2012, 10, 1645.

26 CCDC-959956 (4bg) contains the supplementary crystallographic data for this paper. These data can be obtained free of charge from the Cambridge Crystallographic Data Centre via ww.ccdc.cam.ac.uk/data_request/cif.

27 For this mode of activation, see for instances: a) T. Okino, S. Nakamura, T. Furukawa and Y. Takemoto, Org. Lett., 2004, 6, 625; b) T. Okino, Y. Hoashi, T. Furukawa, X. Xu and Y. Takemoto, $J$. Am. Chem. Soc., 2005, 127, 119; c) X. Xu, T. Furukawa, T. Okino, H. Miyabe and Y. Takemoto, Chem.-Eur. J., 2006, 12, 466.

28 For interesting discussions about reactivity of hydrazines, see: a) Y. Zhao, F. G. Bordwell, J.-P. Cheng and D. Wang, J. Am. Chem. Soc., 1997, 119, 9125; b) A. E. Rosamilia, F. Aricò and P. Tundo, J. Org. Chem., 2008, 73, 1559.

29 P. R. Schreiner and A. Wittkopp, Org. Lett., 2002, 4, 217.

30 E. M. Fleming, T. McCabe and S. J. Connon, Tetrahedron Lett., 2006, 47, 7037.

31 Y. Sohtome, A. Tanatani, Y. Hashimoto and K. Nagasawa, Tetrahedron Lett., 2004, 45, 5589.

32 For the scarce examples of asymmetric organocatalysed aza-Michael addition reactions using nitroalkenes, see: a) J. Wang, H. Li, L. Zu and W. Wang, Org. Lett., 2006, 8, 1391; b) M. Nielsen, W. Zhuang and K. A. Jørgensen, Tetrahedron, 2007, 63, 5849; c) D. Uraguchi, D. Nakashima and T. Ooi, J. Am. Chem. Soc., 2009, 131, 7242; d) X. Liu and Y. Lu, Org. Biomol. Chem., 2010, 8, 4063; e) L. Lykke, D. Monge, M. Nielsen and K. A. Jørgensen, Chem. Eur. J., 2010, 16, 13330; f) D. Uraguchi, N. Kinoshita, T. Kizu and T. Ooi, Synlett, 2011, 1265; g) X.-F. Wang, J. An, X.-X. Zhang, F. Tan, J.-R. Chen and W.-J. Xiao, Org. Lett., 2011, 13, 808; h) S. Ma, L. Wu, M. Liu, Y. Huang and Y. Wang, Tetrahedron, 2013, 69, 2613.
33 For scarce examples, see: a) M. P. Sibi and K. Itoh, J. Am. Chem. Soc., 2007, 129, 8064; b) D. Enders, D. P. Göddertz, C. Beceño and G. Raabe, Adv. Synth. Catal., 2010, 352, 2863; c) Q.-L. Hua, C. Li, X.-F. Wang, L.-Q. Lu, J.-R. Chen and W.-J. Xiao, ACS Catal., 2011, 1, 221; d) Q. Gu and S.-L. You, Chem. Sci., 2011, 2, 1519; e) C. de Fusco, T. Fuoco, G. Croce and A. Lattanzi, Org. Lett., 2012, 14, 4078.

34 Brière and co-workers in Ref $10 \mathrm{j}$, invoke the $\alpha$-effect in the hydrazide to explain the aza-Michael reaction observed in their process.

35 For an interesting mechanistic study of an organocatalysed azaMichael reaction, see: L. Simón and J. M. Goodman, Org. Biomol. Chem., 2009, 7, 483. 